British Journal of Education

Vol.8, Issue 2, pp.44-51, February 2020

Published by $\boldsymbol{E C R T D}-\boldsymbol{U K}$

Print ISSN: ISSN 2054-6351

Online ISSN: ISSN 2054-636X

\title{
THE EFFECT OF USING CONCEPT MAPS TO IMPROVE THE LEVEL OF ACADEMIC ACHIEVEMENT OF STUDENTS AT THE BASIC STAGE IN JORDAN
}

\author{
Samah Taha Younis Mahameed \\ Email: Idgheish@yahoo.com phone number: 00962796174107 \\ Southern Ghour Post Office, Postal code: (61110)
}

\begin{abstract}
This study aimed at assessing the impact of conceptual maps on academic achievement in Islamic education for fifth-grade primary students at Fatima Al-Zahraa Elementary School in Ghour Al-Safi. The sample of this study consisted of two groups, each of which equals (21) students (experimental and controlling). The concept maps required for teaching Islamic education were constructed using the "concept maps" method, while the same content was taught to the control group by the traditional lecture method. The two study groups were pre-tested, and after a two-month teaching period they continued for two months. The two study groups were tested post-test. The results of the study showed that the achievement of the experimental group students was better than the achievement of the control group, and with statistical significance, how the study results showed that the method of concept maps can benefit students who are scholastic, and students who are less distinguished equally.
\end{abstract}

KEYWORD: concept maps, academic achievement, students, improve.

\section{INTRODUCTION}

The increased interest in student learning has led to the emergence of teaching strategies that achieve understanding and better meaning for students. The conceptual mapping method comes among those strategies. Where it was shown and included in his cognitive structure. As many studies have shown, concept maps can achieve multiple educational gains (Al-Faleh, 2005; Al-Rousan, 2004; Guastelo, 2000). Novak \& Gowin (1983) is the first to introduce a conceptual mapping model in order to identify the learner's prior knowledge and to use that knowledge to learn new concepts. Novak built the conceptual mapping strategy on Ausuble (1968) on meaningful learning. In this regard, Ozobel states that new ideas, and knowledge that a student learns are represented within the student's mental structure in the form of a hierarchical structure, where new concepts are contained under higher, more comprehensive concepts. When a student learns a new concept, he searches in his mental structure for a more general concept that can be categorized under it, and the new concept is linked to him through the representation of the hierarchical structure of the subject matter concepts, with maps called concept maps. These conceptual maps help the student to understand the general perception of the teaching material, and to 
British Journal of Education

Vol.8, Issue 2, pp.44-51, February 2020

Published by ECRTD- $\boldsymbol{U K}$

Print ISSN: ISSN 2054-6351

Online ISSN: ISSN 2054-636X

reconstruct and shape his mental conceptual structure, in order to achieve for his assimilation of new concepts and then communicate to understand the best facts.

\section{The study Problem:}

Many students suffer from excessive use of the lecture style, or speech, which is no longer acceptable and is reflected in their academic achievement, and given the importance of acquiring concepts, and their impact on improving student motivation and effective learning, this study came to look for the effect of the conceptual mapping strategy in teaching And find out the importance of this strategy in raising the level of achievement of the fifth-grade students in Islamic education.

\section{Objectives of the study:}

This study aimed at the following:

First: The effect of the concept mapping method on the achievement of fifth-grade primary students in Islamic education.

Second: To what extent is the concept maps method adopted at the achievement level of the students?

\section{Hypotheses of study:}

1. There is no statistically significant difference at the level of significance $(\alpha \geq 0.05)$ between the average achievement of students in the fifth basic class, who are taught Islamic education subject to the traditional lecture method, and those students who are taught using the conceptual mapping method.

2. There is no statistically significant difference at the level $(\alpha \geq 0.05)$ between the achievement of students in the fifth basic class, high achievement, and students with low achievement, due to the difference in the impact of concept maps on achievement according to the level of students 'academic achievement.

\section{The importance of studying:}

The importance of this study is highlighted in the fact that it comes within the framework of the search for teaching methods that lead to students obtaining high-quality teaching. And the development of thinking skills through curricula and teaching strategies practised by teachers inside the classroom.

\section{Study limitations:}

This study is determined as follows:

First: This study was limited to fifth-grade students at Fatima Al-Zahraa Elementary School in Ghor Al-Safi for the year 2019/2020

Second: This study was limited to using conceptual maps in teaching Islamic education for the fifth basic grade. 
British Journal of Education

Vol.8, Issue 2, pp.44-51, February 2020

Published by ECRTD- $\boldsymbol{U K}$

Print ISSN: ISSN 2054-6351

Online ISSN: ISSN 2054-636X

\section{The terminology of study}

Conceptual maps: diagrams, two-dimensional, that define the concepts involved in the content, then arrange them in a hierarchical way, where the general concept, or the principal, is placed at the top of the map, and under it, the less general concepts are graded at the following levels, with links showing the relationships between them in situations Different educational aims, in order to provide the student with meaningful learning, ensure that concepts remain in his cognitive structure (Al-Qarni, 1998). The conceptual maps are defined procedurally in this study as binary fees, showing the concepts of each unit of Islamic education subject in Fatima Al-Zahraa Basic School for Girls, in a hierarchical form, starting with the key concept at the top of the pyramid, to branch from it, and related to it more detailed sub-concepts Set this fee to (Power Pont), to be shown on demo group only.

Academic Achievement: The total score that students obtain in Islamic Education subject after teaching it with a conceptual mapping strategy.

The usual (traditional) method: It is the inductive method that is based on presenting examples, discussing students with them, balancing between them, extracting the base, then training on it, applying it, and starting the particles to reach them all.

\section{Previous studies}

Guastello (2000) conducted a study to identify the impact of conceptual maps on the absorption of the seventh-grade students, who were underachieving the content of science. The study sample consisted of two groups of students, equal in number (162 students each). The first group was taught through reading, and dialogue under the guidance of the teacher, while the second (experimental) group was taught in a similar manner, followed by the presentation of a map of concepts, which displays the main and subsidiary concepts, which were taught. The results of this study showed that the concept map raised the grades of underachievement students. Equivalent to six standard deviations, higher than the traditional teaching method.

Snead \& Young (2003) aimed to use the concept map to help African American students understand middle-school science: the sample of this study consisted of 182 students, distributed according to achievement capacity into eight separate classes. After nine-week teaching, statistical analysis showed that the concept map strategy had a positive impact on statistical significance with students with low educational ability. As for the study of the Russians (2004), it aimed to build a training program to develop the level of conceptual structure using the conceptual mapping strategy of Arabic language teachers who are studying the tenth grade in the Directorate of Education in Amman First District, they were divided in a stratified random manner into two groups: experimental, controlling and forming each group Of (51) male and female teachers. The researcher used a multiplechoice type test to reveal the extent to which the sample members possess the conceptual structure. The results of the study showed that there were statistically significant differences at $(=0.05)$ in favour of the program that was applied to the group. 
British Journal of Education

Vol.8, Issue 2, pp.44-51, February 2020

Published by ECRTD- $\boldsymbol{U K}$

Print ISSN: ISSN 2054-6351

Online ISSN: ISSN 2054-636X

Al-Falih (2005) also conducted a study aimed at investigating the effectiveness of concept maps in developing the ability to perceive relationships, and amending misconceptions in science. The sample of this study consisted of two classes for the experimental group (66 students) and two classes for the control group (64 students). The two study groups were taught for a period of four weeks, during which the researcher used conceptual maps with the experimental group, while the results of this study showed the effectiveness of concept maps in developing the ability to perceive the relationships between concepts and the effectiveness of concept maps in modifying students' misconceptions. In light of all the previous positive indicators of the teaching conceptual mapping method, this study comes as an attempt by the researcher to investigate the effect of that teaching method on the achievement of the fifth basic grade students of Islamic education.

\section{STUDY METHODOLOGY AND PROCEDURES}

\section{Study methodology:}

This study used the experimental approach. Through this approach, it was possible to collect and analyze quantitative data on the achievement of two groups of similar students in everything except that one of them was subjected to the experimental variable, and the other did not.

\section{Study population}

The population of this study are fifth graders in the southern Jordan Ghor, who study Islamic education.

\section{The study sample}

The sample of the study consisted of (42) students from the fifth-grade students at Fatima Al-Zahraa Elementary School in Ghor Al-Safi for the year 2019/2020. The study sample was chosen using the random sample method.

\section{Study tools}

The researcher used the following study tools:

First: Achievement test, prepared by the researcher of a multiple choice type, this test includes (26) questions. All test items covered the content of the teaching material, which was taught to the two study groups, questions were prepared and drafted, to measure the first three levels in Bloom's taxonomy: remembering, understanding, and applying. The researcher used this test at the beginning of the study as a pre-test, and an equivalent image of it was used at the end of the study as a post-test.

Second: The researcher prepared the conceptual maps for the teaching units that were taught in this study, and at the beginning of the study. 


\section{Validity and reliability of the study tools:}

The researcher presented the test he prepared to measure the achievement of students before and after students from fourteen of the arbitrators in the Department of Curricula and Teaching Methods, in order to ensure the quality of the wording of the test items, and that they really measure what they claim to measure. In light of the arbitrators 'opinions on the researcher, the questions could be reformulated to appear in their final form. The stability of the test was calculated using the half-tick method, and it turned out to be (0.74), which is a percentage that can be accepted in the achievement tests. The researcher also presented the conceptual maps that he built on six arbitrators in the field of curricula department to ensure that they display the concepts of the teaching subject and in light of what the researcher received from the opinions of the arbitrators, the concepts could be modified to appear in their final form.

\section{Equality of the groups}

To calculate the effect of the experimental variable for this study, the researcher had to be reassured at the beginning of the study than the control group and the experimental group were equivalent in terms of the achievement ability of students in the Islamic education subject, and this is a condition that must be achieved, in order for the difference in student achievement to be attributed to the experimental variable. Accordingly, the two groups were given a pre-test (the same test was used with the two groups) and using the (T) test the results of the two groups were analyzed on the pre-test, and it was found that there was no significant difference between the achievement of the two study groups, that is, the experimental group and the control group were Equivalent (homogeneous) before the start of the study. Table (1) shows the results of the pre-test analysis for the two study groups.

Table (1) T-test For the independent groups, the difference between the mean groups of the control and experimental groups on the pre-test

\begin{tabular}{|c|c|c|c|c|c|}
\hline Group & mean & sd & T & df & sig \\
\cline { 1 - 3 } experimental & 12.19 & 3.28 & -1.62 & 40 & 0.11 \\
\cline { 1 - 2 } control & 13.95 & 3.26 & & & \\
\hline
\end{tabular}

It is noted through the table that the value of $(\mathrm{T})$ is equal to $(-1.62)$ at the level of significance of (0.11), which is greater than (0.05) (value of alpha), and therefore, we do not reject the null hypothesis, which says "There are no statistically significant differences at the level 0,05 between the experimental and control groups on the pre-test, and this fulfils the condition of random assignment necessary for this study, that is, that the two study groups were equal at the start of the study. 


\section{Application procedures:}

First: A random test was conducted for two divisions from the fifth grade of Islamic education, one of which represents the experimental group, and the other represents the control group.

Second: Concept maps for each teaching unit were prepared on the PowerPoint software, and during the presentation of each unit of study for the experimental group students, the concept map for that unit was displayed on the interactive whiteboard.

Third: Students of the experimental and control groups were given a pre-test that covered all the units covered in the study.

Fourth: The experimental group was taught using conceptual maps for two months, and at the same time, the control group was receiving instruction, covering the same subjects using the traditional method (lecture style).

Fifth: At the end of the application, the two study groups were tested post-test, using an equivalent form of the pre-test.

\section{Statistical processing:}

SPSS in conducting statistical operations, which this study requests, in particular

\section{Presentation of the results of the study hypotheses:}

First: Present the results of the first hypothesis

This hypothesis states, "There is no room for learning the English language of the experimental group that was taught using the concept mapping method, and the control group that was taught in the traditional method."

To examine this hypothesis, a value of $(\mathrm{T})$ was extracted to calculate the difference between the two study groups, and Table No. (2) Illustrates this analysis.

Table No. (2) (T-Test) to calculate the difference between the two study groups on the post-test

\begin{tabular}{|c|c|c|c|c|c|}
\hline Group & mean & sd & T & df & sig \\
\cline { 1 - 3 } experimental & 15.19 & 3.12 & -3.55 & 40 & 0.001 \\
\cline { 1 - 3 } control & 18.19 & 3.72 & & & \\
\hline
\end{tabular}

The results of the table indicate that the value of $(\mathrm{T})$ is $(-3.55)$, which is a function at the significance level (0.001) (less than 0.05). Accordingly, we reject the first zero hypothesis of this study. That is, there are statistically significant differences between the two study groups in favor of the experimental group. This means that the conceptual mapping method used in teaching the experimental group had a positive effect, which has statistical 
significance for students' achievement in Islamic education compared to the traditional teaching method.

Second: Presenting the results of the second hypothesis:

The second hypothesis of this study states that the effect of the conceptual mapping method on achievement does not depend on the level of academic achievement of the targeted students. To verify the hypothesis, the researcher used the unscientific Man-Whiteny Test due to the small sample size. For the purpose of conducting this test, the experimental group was divided into two subgroups (high achievement and low achievement), and based on the results of that group on the pre-test, the impact of the conceptual mapping method was measured by the amount of gain (Gain) on the achievement of each student in each subgroup (That is, the amount of difference between the post-test score and the pre-test score for each student). Table No. (3) shows the results of that.

Table No. (3) Examine the relationship between the impact of conceptual mapping style and students' achievement level

\begin{tabular}{|c|c|c|c|c|}
\hline Group & $\mathrm{N}$ & Average rank & Man-Whiteny & P-Value \\
\hline control & 11 & 11.95 & -3.55 & 40 \\
\hline experimental & 10 & 9.59 & & \\
\hline
\end{tabular}

The results showed that acceptance of the second hypothesis of this study, that is, there are no significant differences between students, high achievement, and students with low achievement, and this means that the teaching conceptual mapping method can benefit all students, regardless of their previous achievement levels.

\section{DISCUSS THE RESULTS}

This study aimed to assess the impact of conceptual maps on the achievement of a group of students in the fifth basic class in Islamic education. To achieve this goal, the researcher prepared conceptual maps and required evaluation methods. The results of this study revealed that there are statistically significant differences between the mean scores of students in the fifth basic class, who were taught using concept maps and students who learned the same subject without using the concept map, for the benefit of students who learned the subject of Islamic education through the method of concept maps. In light of that result, the first hypothesis of this study was rejected, meaning that the concept maps method has a positive impact on students' learning in the fifth basic class of Islamic education.

The results of this study are consistent with the findings of Al-Rousan (2004) and Al-Faleh (2005). The observed positive effect of conceptual maps on academic achievement may be due to the fact that conceptual maps assist the student in organizing concepts, which he is intended to learn and integrate into his existing mental structure in a logical, sequential 
British Journal of Education

Vol.8, Issue 2, pp.44-51, February 2020

Published by ECRTD- $\boldsymbol{U K}$

Print ISSN: ISSN 2054-6351

Online ISSN: ISSN 2054-636X

way, linking it to previous learning. The maps also show the student's concepts of how the sub-concepts relate to each other, and with the main concept, which enhances the coherence of the concepts network within the student's mental structure. In summary, it can be said that the positive impact of concept maps, which this study came out with, is due to the ability of concept maps to link new concepts with previous concepts, and as indicated by the Gaustellom study (2000) that implied that conceptual mapping style may be more effective with students, Mediterranean Capacity compared to students with the highest abilities in their abilities, and as the study results indicated that the achievement of the weak students achievement from the concept map strategy is consistent with the results reached by Gaustellom (2000) and Snead \& Young (2003).

\section{Recommendations:}

Based on the results of this study, the following recommendations can be presented:

1. Encouraging teachers to use concept maps to be one of their teaching strategies, especially since the concept mapping method does not cut into a long period of class time and requires an effort on the part of the teacher at the beginning.

2. Conducting training workshops for teachers on using concept maps in their teaching materials.

\section{References:}

Al-Faleh, Sultana. (2005). The effectiveness of concept maps in developing the ability to perceive relationships and modify misconceptions in the subject of science for second-grade middle school students in Riyadh. Educational Journal, Kuwait University, 77 (20). 163-129.

Al-Rasan, Muhammad. (2004). Building a training program to develop the level of conceptual structure for Arabic language teachers and test its effectiveness. Unpublished doctoral thesis, Al-Ahliyya Amman University.

Ausuble, D. (1968) .Educational Psychology: A Cognitive View. New York Holt, Rinehart $\&$ Winston.

Guastello, F. (2000) .Concept mapping effects on science content comprehension of lowachieving inner-city seventh graders.Remedial \& Special Education, 21 (6) .365364.

Novak, J. and Gowin, D. (1983). The use of concept mapping and knowledge vee mapping with junior high school students. Science Education, 67 (5). 625-645.

Qarni, Zubaida. (1998). The effectiveness of using the concept mapping strategy on both achievement and acquisition of the science process among fifth-grade primary school pupils late in science. Paper submitted to the second scientific conference: Preparing the science teacher for the twenty-first century, 2-5 August, the Egyptian Association for Scientific Education.

Snead, D. and Young, B. (2003) Using concept mapping to aid African American students' understanding in middle grad science. Journal of Negro Education, 72 (3), 333-338. 